\title{
Application of an Integrated Model with MCDM and IPA to Evaluate the Service Quality of Transshipment Port
}

\author{
Chien-Chang Chou ${ }^{1,2}$ and Ji-Feng Ding ${ }^{3}$ \\ ${ }^{1}$ Department of Shipping Technology, National Kaohsiung Marine University, Kaohsiung 805, Taiwan \\ ${ }^{2}$ Chou's Science Research Center, Kaohsiung 805, Taiwan \\ ${ }^{3}$ Department of Aviation and Maritime Transportation Management, Chang Jung Christian University, Tainan 71101, Taiwan
}

Correspondence should be addressed to Chien-Chang Chou; ccchou@mail.nkmu.edu.tw

Received 14 February 2013; Accepted 23 April 2013

Academic Editor: Chang-Hua Lien

Copyright (C) 2013 C.-C. Chou and J.-F. Ding. This is an open access article distributed under the Creative Commons Attribution License, which permits unrestricted use, distribution, and reproduction in any medium, provided the original work is properly cited.

\begin{abstract}
It is often to solve complex decision-making problems in the marine transportation environment, such as the evaluation of service quality and the location choice of ports. In this paper, an integrated model with multiple-criteria decision making (MCDM) and importance-performance analysis (IPA) is presented and then is applied to solve the problem of service quality evaluation of transshipment port. The MCDM approach can be used to deal with both quantitative data and qualitative ratings simultaneously. The IPA approach can be applied to realize the shortcomings of service quality of ports and rank the ranking of strategies for improving service quality of transshipment port. Finally, some useful suggestions for improving the service quality of ports are given in the paper.
\end{abstract}

\section{Introduction}

1.1. Service Quality of Port. Due to a major challenge for the port industry that comes from the increasingly competitive commercial environment in recent years, service quality plays an important role in ports recently. In such a competitive environment where shipping carriers have the choice of using more than just one single port, a port faces the risk of losing its customers, for example, shipping carriers. To maintain its competitiveness in such a competitive and risky shipping market, one port has to invest heavily in equipment and to improve on service quality. Thus, more and more studies on port service quality and performance have been proposed by academic researchers and the departments of ports [1-14].

1.2. Service Quality. Service quality is usually difficult to be evaluated than commodity quality, and it has been defined as a measure of how well the service delivered matches customers' expectations [15]. The same problem of service quality measurement exists in the port industry. It is difficult to measure exactly the service quality of port. In the past, although many approaches and models for evaluating the service quality have been proposed, most of the approaches focused on developing quantitative models for dealing with objective data or qualitative models for dealing with subjective ratings in the evaluation process. Few researchers proposed approaches for dealing with both objective data and subjective ratings simultaneously in the evaluation process of service quality of ports. Thus, this paper attempts to fill this gap in the current literature by developing a multiplecriteria decision-making (MCDM) approach for dealing with objective data and subjective ratings in the evaluation process.

In addition, the past few papers focused on the service gap between the expectation service from the shipping carriers and the real service delivered by ports. Thus, this paper attempts to fill this gap in the current literature by using an importance-performance analysis (IPA) approach for measuring and finding the service gap between the expectation service from the shipping carriers and the real service delivered by ports.

Finally, the integrated model with MCDM and IPA is applied to the evaluation of service quality of three international ports in the Asian region, and then some 
useful suggestions for improving the service quality of three international ports are given in the conclusions of the paper.

\section{Literature Review}

2.1. Evaluation of Service Quality of Port. The service quality, performance, and efficiency of the port industry have been variously studied using either Data Envelopment Analysis (DEA) or Stochastic Frontier Analysis (SFA). Given the strengths and weaknesses associated with these two approaches, the performance evaluations derived from these analyses are not always convincing [16].

Traditionally, the service quality and performance of ports have been evaluated by various approaches to improve or optimize the operational productivity of cargo handling at the container yard [7, 17-19].

In addition, numerous researchers also evaluated the performance and service quality of ports by various methodologies, such as Bayesian stochastic frontier model, mathematical programming, and DEA [4-12].

2.2. MCDM. MCDM approach is a powerful tool for solving complex decision-making problems. MCDM approach has been widely applied to various fields [20], for example, selection of alternative options for environmentally sustainable transportation system [21], forecasting of time series based on soft computing [22], vendor selection in outsourcing [23], supplier selection [24], resource allocation in transportation system [25], and airline safety measurement [26].

In the recent years, some researchers also evaluated the performance and service quality of ports by MCDM methodology $[13,14]$.

2.3. IPA. IPA approach was proposed by Martilla and James [27]. IPA approach can be used to identify the importance and performance of service quality simultaneously. IPA approach has been widely applied to solve the service quality problems since 1977, for example, marketing strategy [28], job satisfaction survey [29, 30], customer relationship [31], customer satisfaction [32,33], satisfaction measurement [34], satisfaction and loyalty [35], and quality of education [36].

The content of IPA is that the survey results are plotted graphically on a two-dimensional grid (Figure 1). The importance of the attribute is displayed on the vertical axis, while the satisfaction level is displayed on the horizontal axis. There are four quadrants in the importance-performance analysis grid: concentrate here, keep up the good work, low priority, and possible overkill. The detailed descriptions of the four quadrants are as follows [37].

In Figure 1, in the first quadrant "concentrate here," the attributes are perceived to be very important to the customers but the service performance levels delivered by the company seem to be below average. This indicates that improvement efforts should be concentrated here. In the second quadrant "keep up the good work," the attributes are perceived to be very important to the customers, and the company performs highly in these service activities. This indicates that the company should continue to keep up the good work in the future. In the third quadrant "low priority," the attributes have low-importance and low performance to the customers. This implies that limited resources should be expended on the attributes belonging to this cell because the attributes are not perceived to be very important by the customers. In the fourth quadrant "possible overkill," it contains lowimportance attributes with relatively high performance. This indicates that the customers are satisfied with the company's service; however, present efforts on the attributes in this cell are overkill and the company should consider resources allocated elsewhere.

Based on the previously mentioned literature review, although IPA approach has been involved in evaluating the service quality of various industries, few researchers applied IPA approach for dealing with the evaluation problem of service quality of maritime industries [38, 39]. Thus, this paper attempts to fill this gap in the current literature by developing an integrated model with MCDM and IPA approaches for evaluating the service quality of ports.

\section{Methodology}

The integrated model with MCDM and IPA involves 7 steps as follows.

Step 1. Develop a hierarchical analysis structure.

Step 2. Present linguistic variables for importance weight of criteria $\left(C_{i}, i=1,2, \ldots, I\right)$ and subcriteria $\left(C_{i j}, i=\right.$ $1,2, \ldots, I, j=1,2, \ldots, J)$, and introduce linguistic variables for ratings for alternatives $\left(A_{n}, n=1,2, \ldots, N\right)$.

Step 3. Determine the importance weights of criteria and then calculate the normalized weights. $W_{i}$ and $W_{i j}$ are the importance weights given by the decision maker to criteria $C_{i}$ and subcriteria $C_{i j}$.

Step 4. The decision maker assesses the subjective ratings for alternatives under qualitative criteria.

Step 5. By (1) and (2), the quantitative scores for alternatives under quantitative criteria are calculated based on the objective data:

$$
R_{i j n}=\left\{\frac{R_{i j n}^{o}}{\max _{i}\left\{R_{i j n}^{o}\right\}}\right\} \times 10,
$$

where $\max _{i}\left\{R_{i j n}^{o}\right\}>0$ and $R_{i j n}$ denotes the transformed rating of quantitative benefit $R_{i j n}^{o}$. $R_{i j n}$ becomes larger when quantitative benefit $R_{i j n}^{o}$ is larger:

$$
R_{i j n}=\left\{\frac{\min _{i}\left\{R_{i j n}^{o}\right\}}{R_{i j n}^{o}}\right\} \times 10,
$$






FIGURE 1: Importance-performance analysis grid.

where $\min _{i}\left\{R_{i j n}^{o}\right\}>0$ and $R_{i j n}$ denotes the transformed rating of quantitative cost $R_{i j n}^{o}$. $R_{i j n}$ becomes smaller when quantitative cost $R_{i j n}^{o}$ is larger.

Step 6. Determine the average importance level and the average performance level.

Step 7. Apply Importance-performance analysis.

\section{An Empirical Study}

This section shows an application of the integrated model with MCDM and IPA to evaluate and analyze the service quality of three international transshipment ports. One shipping company plans to evaluate an appropriate port for container transshipment. After initial screening, three alternative international container ports in the Asian region, including the port $\mathrm{A}\left(A_{1}\right)$, the port $\mathrm{B}\left(A_{2}\right)$, and the port $\mathrm{C}$ $\left(A_{3}\right)$ are selected for further evaluation. The computational procedure is shown as follows.

Step 1. A hierarchical analysis structure is introduced [13]. The hierarchical analysis structure includes 6 criteria and 18 subcriteria. The 6 criteria includes port location $\left(C_{1}\right)$, hinterland economy $\left(C_{2}\right)$, port physical $\left(C_{3}\right)$, port efficiency $\left(C_{4}\right)$, cost $\left(C_{5}\right)$, and other conditions $\left(C_{6}\right)$. These 18 subcriteria in the hierarchical analysis structure can be divided into two categories: quantitative and qualitative criteria. 
TABLE 1: Weight vector.

\begin{tabular}{|c|c|c|c|c|c|c|}
\hline & Weight of $C_{i}$ & Weight of $C_{i j}$ & Normalization & Weight vector & & \\
\hline$C_{1}$ & 3 & & 0.1579 & & & \\
\hline$C_{11}$ & & 4 & 0.3636 & $0.1579 \times 0.3636$ & 0.0574 & 0.6 \\
\hline$C_{12}$ & & 4 & 0.3636 & $0.1579 \times 0.3636$ & 0.0574 & 0.6 \\
\hline$C_{13}$ & & 3 & 0.2728 & $0.1579 \times 0.2728$ & 0.0431 & 0.6 \\
\hline $\mathrm{C}_{2}$ & 4 & & 0.2105 & & & \\
\hline$C_{21}$ & & 5 & 0.3846 & $0.2105 \times 0.3846$ & 0.0809 & 0.6 \\
\hline$C_{22}$ & & 4 & 0.3077 & $0.2105 \times 0.3077$ & 0.0648 & 0.6 \\
\hline$C_{23}$ & & 4 & 0.3077 & $0.2105 \times 0.3077$ & 0.0648 & 0.6 \\
\hline$C_{3}$ & 2 & & 0.1053 & & & \\
\hline$C_{31}$ & & 5 & 0.4167 & $0.1053 \times 0.4167$ & 0.0439 & 0.6 \\
\hline$C_{32}$ & & 4 & 0.3333 & $0.1053 \times 0.3333$ & 0.0351 & 0.6 \\
\hline$C_{33}$ & & 3 & 0.2500 & $0.1053 \times 0.2500$ & 0.0263 & 0.6 \\
\hline $\mathrm{C}_{4}$ & 4 & & 0.2105 & & & \\
\hline$C_{41}$ & & 5 & 0.2941 & $0.2105 \times 0.2941$ & 0.0619 & 0.6 \\
\hline$C_{42}$ & & 3 & 0.1765 & $0.2105 \times 0.1765$ & 0.0372 & 0.6 \\
\hline$C_{43}$ & & 4 & 0.2353 & $0.2105 \times 0.2353$ & 0.0495 & 0.6 \\
\hline$C_{44}$ & & 5 & 0.2941 & $0.2105 \times 0.2941$ & 0.0619 & 0.6 \\
\hline$C_{5}$ & 5 & & 0.2632 & & & \\
\hline$C_{51}$ & & 5 & 0.5000 & $0.2632 \times 0.5000$ & 0.1316 & 0.6 \\
\hline$C_{52}$ & & 5 & 0.5000 & $0.2632 \times 0.5000$ & 0.1316 & 0.6 \\
\hline$C_{6}$ & 1 & & 0.0526 & & & \\
\hline$C_{61}$ & & 5 & 0.4546 & $0.0526 \times 0.4546$ & 0.0238 & 0.6 \\
\hline$C_{62}$ & & 3 & 0.2727 & $0.0526 \times 0.2727$ & 0.0144 & 0.6 \\
\hline $\mathrm{C}_{63}$ & & 3 & 0.2727 & $0.0526 \times 0.2727$ & 0.0144 & 0.6 \\
\hline
\end{tabular}

The quantitative criteria include proximity of the feeder port $\left(C_{12}\right)$, volumes of import/export containers $\left(C_{21}\right)$, volume of transshipment containers $\left(C_{22}\right)$, frequency of ship calls $\left(C_{23}\right)$, infrastructure condition $\left(C_{31}\right)$, port facilities and equipment $\left(C_{32}\right)$, container handling efficiency $\left(C_{41}\right)$, and port charge $\left(C_{51}\right)$. The others are qualitative criteria including: closeness to the import/export area $\left(C_{11}\right)$, closeness to the main navigation route $\left(C_{13}\right)$, intermodal link $\left(C_{33}\right)$, port berthing time length $\left(C_{42}\right)$, container yard efficiency $\left(C_{43}\right)$, custom efficiency $\left(C_{44}\right)$, inland transshipment freight rates $\left(C_{52}\right)$, EDI computer system $\left(C_{61}\right)$, free trade zone $\left(C_{62}\right)$, and port future development plan $\left(C_{63}\right)$. The quantities given to alternatives under subquantitative criteria are defined in quantitative terms (e.g., nautical mile, TEU). The ratings given to alternatives under qualitative subcriteria are defined in linguistic terms represented by 10 scales.

Step 2. The linguistic variables and scores for importance weights of criteria are listed as follows, for example, "Very low $=1$," "Low = 2," "Fair = 3," "High = 4," "Very high = 5." And the linguistic variables and scores for ratings for alternatives are expressed, for example "Very poor $=2$," "Poor $=4$," "Fair $=6$," "Good $=8$," "Very good $=10$."

Step 3. Determine the importance weights of criteria and subcriteria, and calculate the normalized weights in Table 1.
Step 4. The decision maker assesses the subjective ratings for alternatives under qualitative subcriteria in Table 2.

Step 5. The quantitative scores for alternatives under quantitative subcriteria are also calculated based on the objective data in Table 3.

Step 6. Determine the average importance level and the average performance level as the vertical axis and the horizontal axis in Figure 1.

Step 7. Apply Importance-performance analysis.

In Figure 1, most of the points are plotted on the keep up the good work quadrant. That means that the shipping carrier is satisfied with most of services provided by the three international container ports. However, some points are plotted on the concentrate here quadrant. That means some services need to be improved in the future. For example, the port A needs to create more import/export containers, attract more transshipment containers, and increase the frequency of ship call. Decreasing the port charges is the most important for port $\mathrm{B}$. The port $\mathrm{C}$ has to attract more transshipment containers. In addition, some services are plotted on the possible overkill quadrant, that is, the service levels of infrastructure condition, port facilities and equipment, intermodal link, port berthing time length, EDI computer system, free trade 
TABLE 2: Ratings for alternatives under qualitative criteria.

\begin{tabular}{|c|c|c|}
\hline & Qualitative criteria & Rating \\
\hline$C_{11}$ & Closeness to the import/export area & \\
\hline$A_{1}$ & & 10.0 \\
\hline$A_{2}$ & & 10.0 \\
\hline$A_{3}$ & & 8.0 \\
\hline$C_{13}$ & Closeness to the main navigation route & \\
\hline$A_{1}$ & & 10.0 \\
\hline$A_{2}$ & & 10.0 \\
\hline$A_{3}$ & & 8.0 \\
\hline$C_{33}$ & Intermodal link & \\
\hline$A_{1}$ & & 8.0 \\
\hline$A_{2}$ & & 10.0 \\
\hline$A_{3}$ & & 2.0 \\
\hline$C_{42}$ & Port berthing time length & \\
\hline$A_{1}$ & & 8.0 \\
\hline$A_{2}$ & & 10.0 \\
\hline$A_{3}$ & & 6.0 \\
\hline$C_{43}$ & Container yard efficiency & \\
\hline$A_{1}$ & & 8.0 \\
\hline$A_{2}$ & & 10.0 \\
\hline$A_{3}$ & & 6.0 \\
\hline$C_{44}$ & Custom efficiency & \\
\hline$A_{1}$ & & 8.0 \\
\hline$A_{2}$ & & 10.0 \\
\hline$A_{3}$ & & 6.0 \\
\hline$C_{52}$ & Inland transshipment freight rates & \\
\hline$A_{1}$ & & 10.0 \\
\hline$A_{2}$ & & 6.0 \\
\hline$A_{3}$ & & 10.0 \\
\hline$C_{61}$ & EDI computer system & \\
\hline$A_{1}$ & & 8.0 \\
\hline$A_{2}$ & & 10.0 \\
\hline$A_{3}$ & & 4.0 \\
\hline$C_{62}$ & Free trade zone & \\
\hline$A_{1}$ & & 8.0 \\
\hline$A_{2}$ & & 10.0 \\
\hline$A_{3}$ & & 10.0 \\
\hline$C_{63}$ & Port future development plan & \\
\hline$A_{1}$ & & 6.0 \\
\hline$A_{2}$ & & 6.0 \\
\hline$A_{3}$ & & 10.0 \\
\hline
\end{tabular}

zone, and port future development plan. It means that the high efficiency of the port physical and port's other conditions provided by the three international container ports is excess demands of the shipping carrier.

\section{Conclusions}

An integrated model with MCDM and IPA is introduced in this paper. The first submodel that is, MCDM approach can be used to deal with both quantitative data and qualitative
TABLE 3: Quantities and scores for alternatives under quantitative criteria.

\begin{tabular}{|c|c|c|c|}
\hline & Quantitative criteria & Quantity & Score \\
\hline$C_{12}$ & $\begin{array}{l}\text { Proximity of the feeder port (nautical } \\
\text { mile) }\end{array}$ & & \\
\hline$A_{1}$ & & 6356 & 10.0 \\
\hline$A_{2}$ & & 5401 & 8.5 \\
\hline$A_{3}$ & & 7288 & 7.4 \\
\hline
\end{tabular}

$C_{21} \quad$ Volumes of import/export containers

$$
\begin{array}{ccc}
A_{1} & 13731000 & 2.1 \\
A_{2} & 5446000 & 5.3 \\
A_{3} & 25750000 & 10.0
\end{array}
$$

$C_{22} \quad$ Volume of transshipment containers

$\begin{array}{cccc}A_{1} & 10150000 & 4.7 \\ A_{2} & 4810000 & 10.0 \\ A_{3} & 400000 & 0.4 \\ C_{23} & \text { Frequency of ship calls (vessel/week) } & & \\ A_{1} & 435 & 4.1 \\ A_{2} & 177 & 10.0 \\ A_{3} & 206 & 4.7\end{array}$

$C_{31} \quad$ Infrastructure conditions (length of

$\begin{array}{lll}A_{1} & 8530 & 8.7\end{array}$

$\begin{array}{lll}A_{2} & 7453 & 10.0\end{array}$

$\begin{array}{lll}A_{3} & 8387 & 9.8\end{array}$

$C_{32} \quad$ Port facilities and equipment (crane)

$\begin{array}{lll}A_{1} & 84 & 8.0\end{array}$

$\begin{array}{lll}A_{2} & 67 & 10.0\end{array}$

$\begin{array}{lll}A_{3} & 82 & 9.8\end{array}$

$C_{41} \quad$ Container handling efficiency

(move/h)

$\begin{array}{lll}A_{1} & 34 & 9.4\end{array}$

$\begin{array}{lll}A_{2} & 32 & 10.0\end{array}$

$\begin{array}{lll}A_{3} & 30 & 8.8\end{array}$

$C_{51} \quad$ Port charge(\$US/TEU)

$\begin{array}{lll}A_{1} & 338 & 6.4\end{array}$

$\begin{array}{lll}A_{2} & 110 & 2.1\end{array}$

$\begin{array}{lll}A_{3} & 70 & 10.0\end{array}$

Source: Hong Kong Maritime Industry Council web site, http://www.mic.gov .hk/.

Port of Kaohsiung web site, http://www.khb.gov.tw/.

Port of Shanghai web site, http://www.portshanghai.com.cn/.

Containerization International Yearbook

The Institute of Transportation, Ministry of Transportation and Communications, Taiwan.

ratings simultaneously. The second submodel, that is, IPA approach can be applied to realize the shortcomings of service quality and rank the ranking of strategies for improving service quality. Finally, the integrated model is applied to 
evaluate the service quality of three international ports in Asia. The results show that the integrated model is an appropriate one to evaluate and analyze the service quality of ports.

The key findings of this paper are as follows. The shipping carrier is satisfied with most of the services provided by the three international container ports. Regarding the services they are perceived to be very important to the shipping carrier, but the service quality levels as below average are that the ports need to create more import/export containers, attract more transshipment containers, increase the frequency of ship call, and decrease the port charges. The high efficiency of the port physical and port's other conditions provided by the three international container ports is excess demands of the shipping carrier. The present high efforts on the port physical and the port's other conditions are overkill, and the port managers should consider resources allocated elsewhere in the future.

\section{Acknowledgment}

This research work was partially supported by the National Science Council of Taiwan under Grant no. NSC 101-2410-H022-004.

\section{References}

[1] H. Bendall and A. Stent, "On measuring cargo handling productivity," Maritime Policy and Management, vol. 14, no. 4, pp. 337-343, 1987.

[2] J. L. Tongzon, "Determinants of port performance and efficiency," Transportation Research A, vol. 29, no. 3, pp. 245-252, 1995.

[3] E. Martinez-Budria, R. Diaz-Armas, M. Navarro-Ibanez, and T. Ravelo-Mesa, "A study of the efficiency of Spanish Port authorities using data envelopment analysis," International Journal of Transport Economics, vol. 26, no. 2, pp. 237-253, 1999.

[4] T. Noteboom, C. Coeck, and J. van den Broeck, "Measuring and explaining the relative efficiency of container terminals by means of Bayesian stochastic frontier models," International Journal of Maritime Economics, vol. 2, no. 2, pp. 83-106, 2000.

[5] P. Coto-Millan, J. Banos-Pino, and A. Rodriguez-Alvarez, "Economic efficiency in Spanish ports: some empirical evidence," Maritime Policy and Management, vol. 27, no. 2, pp. 169-174, 2000.

[6] J. Tongzon, "Efficiency measurement of selected Australian and other international ports using data envelopment analysis," Transportation Research A, vol. 35, no. 2, pp. 107-122, 2001.

[7] C. Y. Chu and W. C. Huang, "Aggregates cranes handling capacity of container terminals: the port of Kaohsiung," Maritime Policy and Management, vol. 29, no. 4, pp. 341-350, 2002.

[8] K. Cullinane, "The productivity and efficiency of ports and terminals: methods and applications," in The Handbook of Maritime Economics and Business, C. T. Grammenos, Ed., pp. 803-831, Informa Professional, London, UK, 2002.

[9] K. Cullinane, D. W. Song, and R. Gray, "A stochastic frontier model of the efficiency of major container terminals in Asia: assessing the influence of administrative and ownership structures," Transportation Research A, vol. 36, no. 8, pp. 743-762, 2002.
[10] K. Cullinane and D. W. Song, "A stochastic frontier model of the productive efficiency of Korean container terminals," Applied Economics, vol. 35, no. 3, pp. 251-267, 2003.

[11] K. Cullinane, D. W. Song, P. Ji, and T. F. Wang, "An application of DEA windows analysis to container port production efficiency," Review of Network Economics, vol. 3, no. 2, pp. 186-208, 2004.

[12] J. Tongzon and W. Heng, "Port privatization, efficiency and competitiveness: some empirical evidence from container ports (terminals)," Transportation Research A, vol. 39, no. 5, pp. 405424, 2005.

[13] C. C. Chou, "A fuzzy logic approach to dealing with objective data and subjective rating," International Journal of Innovative Computing, Information and Control, vol. 6, no. 5, pp. 21992209, 2010.

[14] C. C. Chou, "An integrated quantitative and qualitative FMCDM model for location choices," Soft Computing, vol. 14, no. 7, pp. 757-771, 2010.

[15] R. C. Lewis and B. H. Booms, "The marketing aspects of service quality," in Emerging Perspectives on Service Marketing, G. Shostack, L. Berry, and G. Upah, Eds., pp. 99-107, American Marketing, Chicago, Ill, USA, 1983.

[16] K. Cullinane, T. F. Wang, D. W. Song, and P. Ji, “The technical efficiency of container ports: comparing data envelopment analysis and stochastic frontier analysis," Transportation Research A, vol. 40, no. 4, pp. 354-374, 2006.

[17] M. Avriel, M. Penn, and N. Shpirer, "Container ship stowage problem: complexity and connection to the coloring of circle graphs," Discrete Applied Mathematics, vol. 103, no. 1-3, pp. 271$279,2000$.

[18] I. D. Wilson and P. A. Roach, "Container stowage planning: a methodology for generating computerized solutions," Journal of the Operational Research Society, vol. 51, no. 11, pp. 1248-1255, 2000.

[19] A. Imai, E. Nishimura, S. Papadimitriu, and K. Sasaki, “The containership loading problem," International Journal of Maritime Economics, vol. 4, pp. 126-148, 2002.

[20] C. L. Hwang and K. Yoon, Multiple Attributes Decision Making Methods and Applications, Springer, Berlin, Germany, 1981.

[21] S. Yedla and R. M. Shrestha, "Multi-criteria approach for the selection of alternative options for environmentally sustainable transport system in Delhi," Transportation Research A, vol. 37, no. 8, pp. 717-729, 2003.

[22] J. D. Bermúdez, J. V. Segura, and E. Vercher, "A decision support system methodology for forecasting of time series based on soft computing," Computational Statistics \& Data Analysis, vol. 51, no. 1, pp. 177-191, 2006.

[23] V. Wadhwa and A. R. Ravindran, "Vendor selection in outsourcing," Computers and Operations Research, vol. 34, no. 12, pp. 3725-3737, 2007.

[24] W. J. Xia and Z. M. Wu, "Supplier selection with multiple criteria in volume discount environments," Omega, vol. 35, no. 5, pp. 494-504, 2007.

[25] W.-M. Wey and K.-Y. Wu, "Using ANP priorities with goal programming in resource allocation in transportation," Mathematical and Computer Modelling, vol. 46, no. 7-8, pp. 985-1000, 2007.

[26] J. J. H. Liou, G. H. Tzeng, and H. C. Chang, "Airline safety measurement using a hybrid model," Journal of Air Transport Management, vol. 13, no. 4, pp. 243-249, 2007.

[27] J. A. Martilla and J. C. James, "Importance- performance analysis," Journal of Marketing, vol. 41, pp. 77-79, 1977. 
[28] J. M. Hawes and C. P. Rao, "Using importance-performance analysis to develop health care marketing strategies," Journal of Health Care Marketing, vol. 5, no. 4, pp. 19-25, 1985.

[29] D. R. Bacon, "A comparison of approaches to importanceperformance analysis," International Journal of Market Research, vol. 45, no. 1, pp. 55-71, 2003.

[30] J. K. Eskildsen and K. Kristensen, "Enhancing importanceperformance analysis," International Journal of Productivity and Performance Management, vol. 55, no. 1, pp. 40-60, 2006.

[31] M. W. Lowenstein, Customer Retention: An Integrated Process for Keeping Your Best Customers, ASQC Quality Press, Milwaukee, Wis, USA, 1995.

[32] R. Chu, "Stated-importance versus derived-importance customer satisfaction measurement," Journal of Services Marketing, vol. 16, no. 4, pp. 285-301, 2002.

[33] K. Matzler, E. Sauerwein, and K. A. Heischmidt, "Importanceperformance analysis revisited: the role of the factor structure of customer satisfaction," The Service Industries Journal, vol. 23, no. 2, pp. 112-129, 2003.

[34] R. L. Oliver, Satisfaction, Mcgraw-Hill, Boston, Mass, USA, 1997.

[35] J. K. Eskildsen and M. L. Nüssler, "The managerial drivers of employee satisfaction and loyalty," Total Quality Management, vol. 11, no. 4-6, pp. S581-S588, 2000.

[36] A. Martensen, L. Grønholdt, J. K. Eskildsen, and K. Kristensen, "Measuring student oriented quality in high education: application of the ESCI methodology," Sinergie Rapporti di Ricerca, vol. 9, no. 18, pp. 371-383, 2000.

[37] F. Y. Chen and Y. H. Chang, "Examining airline service quality from a process perspective," Journal of Air Transport Management, vol. 11, no. 2, pp. 79-87, 2005.

[38] J. Ko, Y. Cho, J. Choi, and T. H. Kim, "Evaluation of travel demand management strategies using importanceperformance analysis," Transportation Research Record, no. 2118, pp. 67-74, 2009.

[39] T. W. Lee and K. C. Hu, "Evaluation of the service quality of container ports by importance-performance analysis," International Journal of Shipping and Transport Logistics, vol. 4, no. 3, pp. 197-211, 2012. 


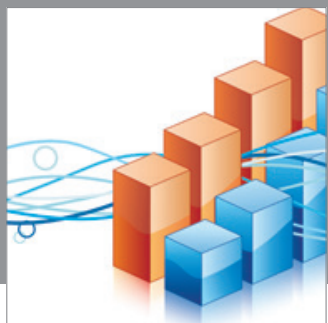

Advances in

Operations Research

mansans

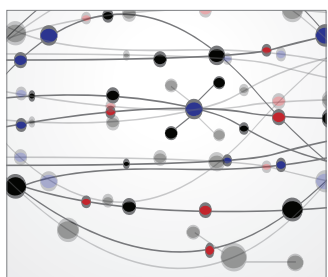

The Scientific World Journal
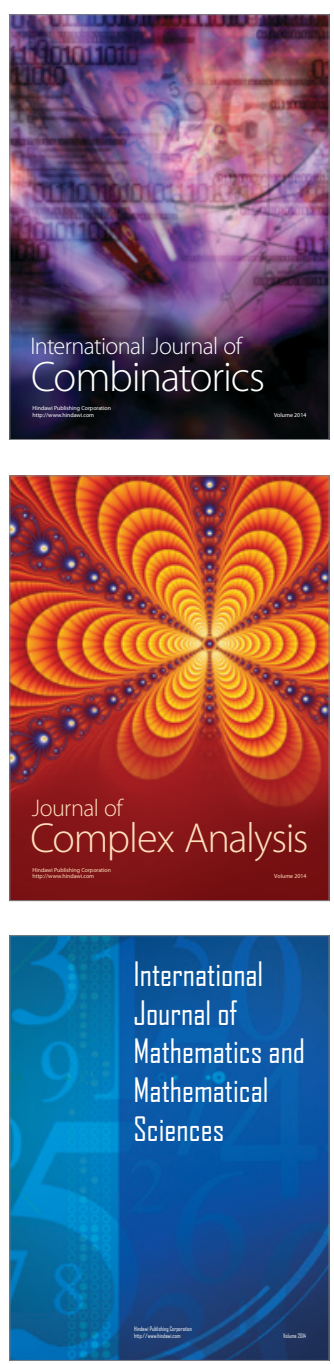
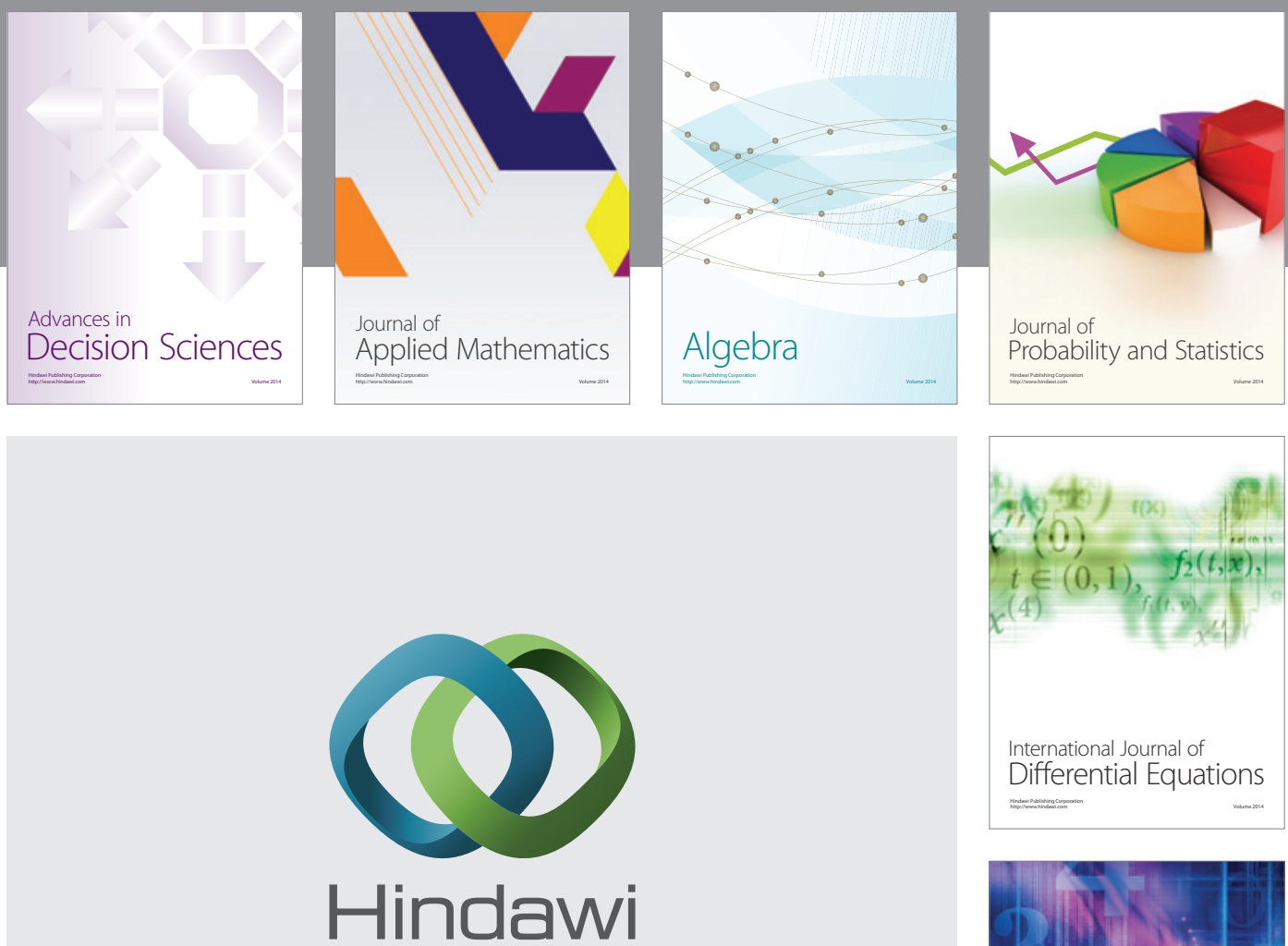

Submit your manuscripts at http://www.hindawi.com
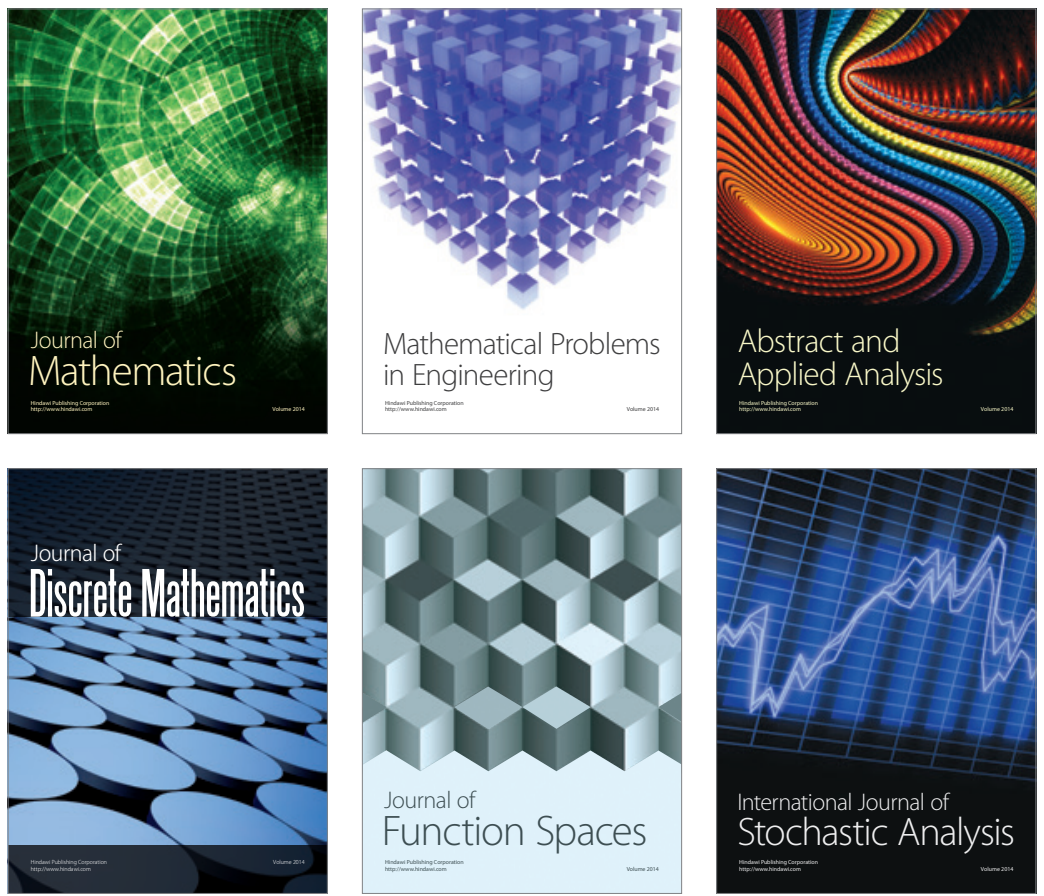

Journal of

Function Spaces

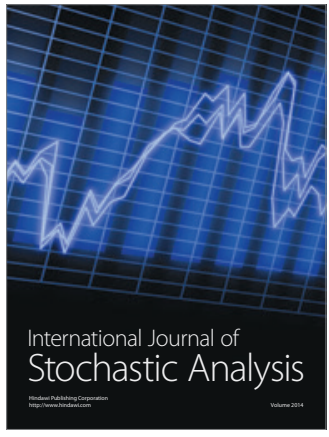


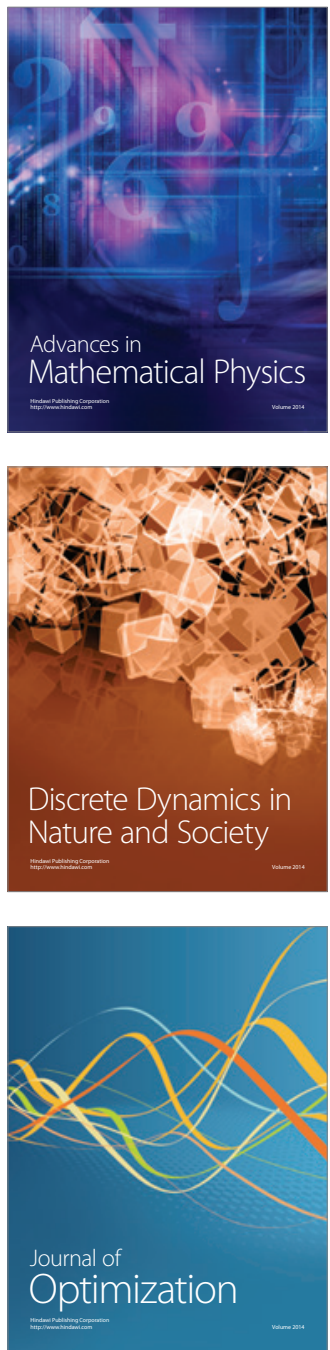